\title{
Does Who Decides Really Matter? Causes and Consequences of Personal Financial Management in the Case of Larger and Structural Charitable Donations
}

\author{
Pamala Wiepking • René Bekkers
}

Published online: 29 January 2010

(C) The Author(s) 2010. This article is published with open access at Springerlink.com

\begin{abstract}
We study causes and consequences of financial management in households in the specific case of charitable giving. We test hypotheses using couples in the Giving in the Netherlands Panel Study $(n=1,101)$. We find that more relationship specific investments lead to deciding on charitable giving as one economic actor. Furthermore, we find that the partner with the highest relative educational resources has most decision making power over charitable donations. Separately deciding couples are smallest charitable donors. Households in which the male partner decides are largest charitable donors when only larger and more structural donations are considered. This can be explained by their more conservative religious denomination.
\end{abstract}

Résumé Notre étude porte sur les causes et les conséquences de la gestion financière des ménages pour le cas spécifique des dons caritatifs. Nous testons des hypothèses à travers un panel de quelques couples des Pays-Bas (GINPS) en matière de dons $(n=1,101)$. Nous trouvons que davantage d'investissements spécifiques relationnels conduisent à prendre en compte le don caritatif en tant qu'acteur économique. En outre, nous trouvons que le conjoint au revenu le plus élevé détient le plus de pouvoir décisionnel quand il s'agit de faire des dons de charité. Les couples qui prennent les décisions séparément sont les donateurs les plus modestes. Lorsque des dons structurels importants sont envisagés, les ménages dans lesquels l'homme prend les décisions sont les donateurs les plus généreux. Une confession religieuse conservatrice peut venir expliquer cette conduite.

\footnotetext{
P. Wiepking $(\bowtie) \cdot$ R. Bekkers

Faculty of Social Sciences, Department of Philanthropy, VU University Amsterdam, De Boelelaan 1081, $1081 \mathrm{HV}$ Amsterdam, The Netherlands

e-mail: P.Wiepking@fsw.vu.nl

R. Bekkers

e-mail: R.Bekkers@fsw.vu.nl
} 
Zusammenfassung Wir untersuchen Gründe und Folgen der Verwaltung der Haushaltsfinanzen speziell bezogen auf das Spenden für wohltätige Zwecke. Wir testen Hypothesen an Paaren im Projekt Giving in the Netherlands Panel Study $(n=1,101)$. Wir finden, dass Paare bei beziehungsspezifischeren Investitionen eine Spendenentscheidung als eine ökonomische Einheit treffen. Außerdem entdecken wir, dass der Partner mit dem höchsten relativen Bildungsniveau die größere Entscheidungsbefugnis über wohltätiges Spenden hat. Paare, wo Partner separat entscheiden, spenden am wenigsten. Haushalte, in denen der männliche Partner entscheidet, sind die größten Spender bei größeren und strukturelleren Spenden. Dies kann mit deren Zugehörigkeit zu konservativeren Glaubensgemeinschaften erklärt werden.

Resumen Hemos estudiado las causas y las consecuencias de la administración económica de los hogares en el caso específico de las donaciones caritativas. Probamos diversas hipótesis con parejas dentro del Estudio del Panel de las Donaciones en los Países Bajos $(n=1,101)$. El resultado es que las inversiones específicas de relación llevan a decidir sobre las donaciones caritativas como un actor económico. Asimismo, hemos descubierto que el cónyuge con más recursos educativos tiene más poder de decisión sobre las donaciones caritativas. Las parejas que deciden por separado son donantes de menor envergadura, mientras que los hogares en los que decide el cónyuge masculino son donantes de más envergadura, solo cuando se tienen en cuenta más y mayores donativos estructurales. Esto puede explicarse por su carácter religioso más conservador.

Keywords Financial management · Households · Philanthropy · Charitable giving $\cdot$ Donations

\section{Introduction}

In a focus group study investigating how couples decide on charitable giving, Burgoyne et al. (2005) quote a participant elaborating on decision making on charitable donations in his household:

'It's only things like direct debits that come under the household budget because that's a regular payment that's paid out of the household total budget ... So that side of it is definitely household decision, so it's reviewed, almost, every year when we get the bills and you decide what you're going to carry on with or not. The caller at the door or other things is more of individual.' (Burgoyne et al. 2005, p. 391)

Burgoyne et al. (2005) conclude that this respondent's statement is typical for the way in which couples decide on charitable giving. The larger and more structural donations are decided on jointly, and the smaller incidental donations are based on individual decisions. In the first section of this study, we investigate whether this statement is representative for charitable decision making in Dutch households. 
How do partners in a household make decisions on charitable giving? Do Dutch couples decide jointly on charitable giving most of the time?

In the second part of this study we focus on the consequences of this charitable decision making. In study on charitable giving by American households, Andreoni et al. (2003) find that how partners in households decide on charitable giving influences the amount they donate. Households in which the male partner singlehandedly decides on charitable giving donate higher amounts than households with female decision makers. And households in which partners decide jointly are lowest donors on average. We investigate the effects of financial management in households on the level of charitable giving in the Netherlands.

These questions are important, as most research on charitable giving assumes that decisions on donations are household decisions, rather than individual decisions. Knowing how partners in a household make these decisions, and discover what the consequences of these decisions are will first of all facilitate better understanding of the process of making charitable donations. In addition, information on how couples decide on charitable giving can also be very useful to charitable organizations attempting to increase fundraising effectiveness. Knowing which partner makes what kinds of decisions on charitable donations can help fundraisers to more strategically make requests for donations.

We focus on the Netherlands because of the availability of data with a high quality measure of financial decision making in households. We use the Giving in the Netherlands Panel Study 2005 (GINPS05 2005). In GINPS05, 1,474 respondents reported on both their own and (if applicable) on their partner's financial decision making and donating behavior in 2005. In addition, GINPS05 contains the necessary demographic and socio-economic background variables for this study.

\section{Conceptual Framework}

\section{Determinants of Decision Making on Charitable Giving}

In their focus group study Burgoyne et al. (2005) conclude that partners in general decide individually rather than as a couple over smaller incidental donations, like door-to-door collections, or street collections. The story is different when larger and more structural donations are considered. In these cases, charitable giving is considered a 'normal' household expenditure. Decisions on these expenditures follow the 'normal' rules for financial decision making in a household. Thus, how a couple decides on more structural donations depends for a large part on the general system of financial organization present in a household. In this study, we will focus on decision making in the case of these somewhat larger and more structural donations.

Pahl (1983, 1995) and Vogler (2005) have developed a widely used typology of general financial management in relationships, based upon whether couples operate as a single or as two separate economic units. According to Pahl and Vogler's typology, when couples operate as a single economic unit (which we further refer to as 'one economic actor'), the couple can allocate their money using three 
mechanisms: First, couples can arrange family finances according to the whole wage system, in which all money is managed by one partner, who distributes some spending money to the other partner. Second, couples can allocate money by means of the housekeeping allowance system. In this system one spouse-usually the husband-gives the other partner money to pay for daily household expenditures and controls the rest of the money. Third, couples can share their income using the joint pooling system. In this system, partners use a 'common' pot to pay for joint expenses, and take some individual spending money out of this pot.

When couples function as two separate economic units (which we further refer to as 'two economic actors'), they can either choose to allocate their money by means of the partial pooling system or by means of the independent management system. In the partial pooling system a couple pools some of their income to pay for collective expenditures, but keeps most of the money separate. In the independent management system partners keep purses completely separate.

Except a study by Giesen and Kalmijn (1999), no research has been conducted on general financial management systems in the Netherlands, let alone on financial decision making in the case of charitable giving. The results by Giesen and Kalmijn indicate that financial management by Dutch couples can be deduced to the type of relationship. Married couples pool their income and decide on most finances jointly, and cohabiting couples have separate accounts and make individual financial decisions. Additional results show that Dutch couples more often have joint accounts when they are lower educated, have children, and are politically right oriented. In this study we will investigate whether these general results resemble financial decision making with respect to charitable giving.

In general research on financial management in households three theories prevail: Sunk cost theory, resource theory, and gender role theory (e.g., Treas 1993; Pahl 1995; Heimdal and Houseknecht 2003). These three theories all identify different sets of determinants of financial management in households. We implement these theories in order to predict the financial management system that couples use for charitable giving. We start with sunk cost theory.

Sunk cost theory predicts that financial management in households is determined by the level of relation-specific investments partners have made (Treas 1993). The more relation-specific investments a couple has made, the more likely it is that they will pool their money and function as one economic actor. As Treas puts it: 'Marriage-specific investments call for collectivization' (Treas 1993, p. 725). The less relation-specific investments, the higher the probability partners decide separately on monetary issues. In addition, when the risk of separation is higher, people will be less inclined to make relationship-specific investments (Heimdal and Houseknecht 2003; Kenney 2006). Indicators for relation-specific investments are for example home ownership, and taking care of children.

Results of past research are in line with Treas' argument about sunk costs. Couples in which one of the partners has experienced the disruption of a former relationship — either in the form of a divorce or by the decease of a partner-more often keep money separate, and thus function as two economic actors (Treas 1993; Heimdal and Houseknecht 2003; Vogler et al. 2006). The same holds for cohabiting couples, who-in contrast to married couples-more often use separate purses 
(Giesen and Kalmijn 1999; Treas and Widmer 2000; Heimdal and Houseknecht 2003; Vogler 2005; Vogler et al. 2008).

From sunk cost theory we predict that couples with more relation-specific investments (such as home ownership and the number of children) will more often function as one economic actor. Hence they will use one of the systems in which partners decide as one actor on financial expenditures in order to make charitable donations. In addition, we also predict that couples who have previously experienced a serious relationship disruption will be more careful to make relationship-specific investments, and prefer to act as two separate economic actors.

From resource theory we can deduce two different predictions about financial management in households, which depend on either absolute or relative socioeconomic resources. With respect to absolute resources, researchers argue that higher levels of absolute resources enable partners to achieve goals without the help of their spouse and give them more bargaining power over financial decisions, such as charitable donations (Williamson 1975; Blumstein and Schwartz 1983; Treas 1993). Woolley (2000) for example showed that when the male partner has a higher income, he is more likely to control financial management, a result also confirmed by Richie (1990) in Waseem 2004). Additionally, according to both Vogler (1998) and Pahl (1983), women who are employed are more likely to have control over financial management, irrespective of their income. Furthermore, Treas (1993) found that couples in which the wife works are more likely to have separate accounts. Therefore, from resource theory we first predict that couples with less financial and educational resources are more likely to pool income, and hence make charitable donations as one economic actor.

Relative resource theory predicts who in the relationship has most control over money, when couples decide as one actor. According to this theory, the level of control over financial management of a spouse increases with their level of socioeconomic resources or knowledge about finances relative to that of their partner (Treas 1993; Pahl 1995; Woolley 2000; Andreoni et al. 2003; Kenney 2006). When a man has a higher income, completed a higher educational level or has significantly more knowledge of financial matters than his female partner, his control over a household's pooled money is larger (Waseem 2004; Kenney 2006). The same argument is valid for control over financial management by women. When their income, educational level, or knowledge of financial matters is higher than that of their male partners, they will have more to say about the household's pooled money. When we implement relative resource theory in order to predict the financial management system couples use for charitable giving, we argue that in the case where couples make monetary decisions as one actor, the partner with highest level of financial and educational resources will be in control of the pooled money.

Finally, gender role theory states that traditional views on gender roles may impose limits to the financial management options of women (Thornton et al. 1983; Lundberg and Polak 1996; Kenney 2006). In families with more traditional values, household finances are more likely to be characterized by the allowance system or by the male controlled pooling system, as handling money is traditionally regarded a male task (Tichenor 1999). Ludwig-Mayerhofer (2000) shows that in Germany, traditional gender values indeed lead to a higher likelihood of male controlled 
financial management. Treas and Widmer (2000) studied money management in 23 countries, and find that both the individual approval of women's employment and the mean level of women employed in a country have a positive effect on keeping money separate. Kenney (2006) found that more traditional views on gender roles increase the likelihood of the use of a male controlled pooling system in the United States. In contrast, Heimdal and Houseknecht (2003) found no effect of gender values on a couple's financial management system in both Sweden and the United States. They gave no explanation for this deviant result. From gender role theory we predict that couples with more traditional views on gender roles will more often donate money to charitable causes as one economic actor and have the male partner decide on these expenditures.

\section{Consequences of Financial Management}

In this paragraph we discuss the consequences of different financial management systems for the amount couples decide to donate to charitable causes. Previous research on charitable giving by married couples in the United States shows that households in which the male partner decides on charitable giving make largest donations to charitable causes. Households in which the female partner decides or where joint decisions are made are smaller donors (Andreoni et al. 2003). Do these differences also exist in the Netherlands? And if so, why would different financial management systems lead to differences in expenditures on charitable giving?

\section{Financial Management as One Economic Actor}

We start with arguments about the consequences of managing finances when couples decide upon expenditures as one economic actor. As discussed, according to Pahl (1983, 1995) and Vogler (2005) there are three mechanisms along which couples can arrange financial management as one economic actor: (a) the whole wage system, (b) the allowance system, and (c) the pooling system.

When couples arrange their finances according to the whole wage system or the allowance system, one partner controls all financial resources, and hence couples have no discussion about expenditures. The results by Andreoni et al. (2003) show that it does matter specifically for the level of charitable giving whether the male or the female partner controls the whole wage or allowance system. With gender role theory we can account for this difference. Couples with more traditional gender role values are more likely to have the male partner in control of financial management. At the same time, couples with more traditional gender values are also likely to be members of more conservative denominations (Jansen 2002). And in the Netherlands, members of conservative denominations are also known to be large charitable donors (Bekkers and Schuyt 2008). Hence, from gender role theory we predict that couples arranging financial management as one economic actor by means of the male controlled whole wage or allowance system are large charitable donors because of their more conservative religious denomination and the more traditional gender role values connected to this religion. 
When couples arrange financial management with the pooling system, partners take spending money out of a common pot, and use the rest of the money to pay for joint expenses. Using the pooling system, couples can either jointly decide about charitable giving, or use their personal spending money to make charitable donations. In the latter case the couple acts as two economical actors, a situation that is discussed later.

According to signalling theory, partners give each other incentives to donate higher amounts to charitable organizations. Signalling theory emphasizes the private benefits for spouses in negotiations on charitable giving. It is well known that people have a preference to select partners with pro-social attitudes and personality characteristics on the marriage market (Buss and Barnes 1986; Botwin et al. 1997), and it is likely that these traits contribute to maintenance of the marital relationship. In order to maintain a good marital relationship, spouses have an incentive to appear to each other as cooperative, trusting, empathic, and having high moral standards (Milinski et al. 2002; Wedekind and Braithwaite 2002). We argue that spouses use charitable giving strategically in order to signal their pro-sociality to each other. Donating higher amounts to charitable organizations can signal a partner's pro-sociality, but only under the condition that partners agree-at least to some extent-with each other on donations. It is hard to signal pro-sociality while donating to organizations that the partner disagrees of. From signalling theory we predict that having similar preferences for charitable giving will increase the amount donated to charitable organizations.

Transaction cost theory predicts that most couples will try to make joint financial decisions in a way that causes them least time and trouble. Partners try to minimize their transaction costs, which have to do with negotiating and coordination of financial management (Williamson 1981; Treas 1993; Andreoni et al. 2003). According to transaction cost theory, when partners jointly decide it matters whether or not they agree with each other on charitable giving. When partners have opposing preferences on charitable contributions, the amount of time required to reach decisions on charitable contributions will be higher. In addition to that, when partners have opposing tastes, the charitable donation of one partner creates 'negative externalities' experienced by the other partner, and this will reduce the donations of a jointly deciding couple drastically (Andreoni et al. 2003, p. 113). On the other hand, when partners have similar preferences for charitable giving, it takes little time to make decisions about the charitable expenditures and this is likely to benefit the amounts donated to charitable causes. From transaction cost theory we predict that when jointly deciding couples have similar tastes for giving, this will increase the amount donated. But when jointly deciding couples have opposing tastes, this will decrease the amount donated.

\section{Financial Management as Two Economic Actors}

When partners function as two separate economic actors, they will make charitable donations out of their own financial accounts, no matter whether they allocate their money by means of the partial pooling system or by means of the independent 
management system. According to transaction cost theory separate financial decision making results in higher levels of giving than financial decision making as a single actor (Andreoni et al. 2003). This argument is based on the assumptions that each partner receives utility for making charitable donations, that the utility of each donated dollar is equal for both partners, and that both jointly and separately deciding actors strive for the same level of utility.

Assume that $\$ 1$ equals 1 'utility'-unit. When a couple donates $€ 20$ jointly (as a single economic actor), both partners receive 20 utility-units. In a situation where both partners separately donate $€ 10$, the total amount received by the charity is also $€ 20$, but both partners receive only 10 utility-units. In this example, in order to achieve the same level of utility, separately deciding partners need to donate twice the amount of couples deciding as one economic actor in order to achieve the same level of utility. From transaction cost theory we predict that couples deciding as two economic actors will donate higher amounts than couples deciding as one economic actor.

\section{Data}

The Giving in the Netherlands Panel Study

We use data from the third wave of the Giving in the Netherlands Panel Study (GINPS05 2005). The GINPS is a bi-annual longitudinal study on charitable giving and volunteering in the Netherlands, which started in 2001. In May 2006, 1,868 persons were questioned about their donating behavior in 2005. In total, 1,474 respondents $(79 \%)$ completed the questionnaire, using Computer-Assisted SelfAdministered Interview procedures (CASI).

We are interested in financial decision making in couple households. Therefore, we selected only households in which respondents are involved in a relationship. ${ }^{1}$ This selection reduced our sample to 1,103 respondents, of which 892 (81\%) are married, 151 (14\%) are unmarried cohabiting, and 60 (5\%) are 'Living Apart Together' (LAT; couples in which partners live separately from one another). This is representative for national figures of types of partnerships in the Netherlands (Dijkstra and Komter 2004; Eurostat 2005). In addition, we excluded two cases with a monthly after tax household income over $€ 11,000$ from the analyses, because these cases influenced the results significantly. ${ }^{2}$ This reduced the sample used in the analyses to 1,101 cases.

\footnotetext{
$197.5 \%$ of the respondents are involved in heterosexual relationships, while 19 male respondents and 9 female respondents are involved in same sex relationships. These 28 respondents are included in the analyses.

2 In the OLS regression analyses Dfbeta for these cases was -0.061 and -0.054 . This is higher than abs(dfbeta) $>2$ /sqrt $\mathrm{N} \sim \operatorname{abs}($ dfbeta) $>2$ /sqrt $1474 \sim \operatorname{abs}$ (dfbeta) $>0.052$, which indicates that these cases are influential outliers, including these two cases in the analyses affects the results significantly.
} 


\section{Measures of Dependent Variables}

The first dependent variable measures whether a couple in general makes decisions on charitable donations over $€ 10$ as one economic actor. ${ }^{3}$ In order to obtain this information, we asked respondents whether (a) the respondent and partner make decisions on charitable giving separately; (b) whether the respondent decides; (c) whether the respondent's partner decides or (d) whether the respondent and partner decide jointly. Couples in which partners decide separately are regarded as deciding as two economic actors (16\%), all others are considered to be deciding as one economic actor $(84 \%)$. We included the minimum amount of $€ 10$ in the question to specifically investigate decision making on somewhat larger and more structural donations, and exclude decision making on incidental small donations (such as door-to-door or street collections).

The second dependent variable is a measure of financial decision making authority in the case where couples decide as one economic actor. By combining the reports on couples' decision making with the respondents gender, we create dichotomous variables for the female partner decides (18\%), the male partner decides (10\%), or decisions are made jointly (72\%).

To investigate the effects of financial management on charitable donations, we construct the amount of money a household donated to various charitable causes in 2005. We are first and foremost interested in the different effects of decision making on structural (larger) donations. However, we also want to compare charitable decision making on larger donations with decision making on total donations. Therefore, we construct two variables for the amount households donated. The first variable measures total amount donated in 2005 for all donations. The second variable is limited to the amount donated for households donating more than $€ 50$ in 2005, which likely excludes most households that only make small spontaneous donations. 702 couple households (64\%) have donated over $€ 50$ in total in 2005 .

The amount of money a household donated in 2005 is measured with questions on donations to eleven different categories of charitable causes. The questionnaire uses a survey module that minimizes the risk that people underreport donations. ${ }^{4}$ First, respondents were questioned about which method they used to make a donation, for example, a donation canister or a credit slip. After that, for each category of charitable causes, respondents were asked whether or not their household had made a donation. Third, the respondents reported the amount donated in 2005 to each of the categories they indicated having donated to. Out of the sample of 1,101 households, 258 (23\%) did indicate to have made a donation to one or more specific sub-sector(s), but failed to specify the exact amount. In these cases, the missing amounts were imputed independently for each charitable sub-sector using the complete original dataset $(N=1,474)$. One problem with using multiple imputation in giving data is that the missing values are not Missing at Random (MAR), an assumption that needs to be satisfied when imputing missing data

\footnotetext{
3 It is made clear to the respondents that these decisions refer to separate instances of making donations (larger than $€ 10$ ) to particular charitable organizations.

4 This survey module is labeled 'Method-Area'-module in Rooney et al. (2001).
} 
(Allison 2002). This is problematic, but multiple imputation seems the best solution for dealing with missing values in giving data. See Brooks (2004) for more information and a discussion on using multiple imputation in charitable giving data. Multiple imputation uses linear predictions, which can result in negative donations. This is a minor problem, as after imputation only $1 \%$ of the donations are negative. In line with Schafer (1997) we substitute all donations below 1 with a donation of $€ 1$. This enables us to calculate and use the natural log of the total amount donated and the natural log of total amount donated for households donating more than $€ 50$ as third and fourth dependent variable.

\section{Measures of Predictor Variables}

Difference in educational level between husband and wife is composed by subtracting the wife's education from that of the husband's. Mean educational level consists of the sum of the educational level of both partners, divided by two. Educational level of both partners is measured on a seven-point scale, with (1) only primary education; (2) primary education and some vocational school; (3) lower secondary education; (4) middle secondary education; (5) higher secondary education; (6) higher vocational education; (7) higher tertiary education. ${ }^{5}$

Difference in monthly after-tax income (in $€ 1,000$ ) between husband and wife is composed by subtracting the wife's income from that of the husband's. ${ }^{6}$ Mean income in $€ 1,000$ consists of the sum of monthly after-tax income of both partners, divided by two. Monthly after-tax income is measured for both the respondent and partner by asking for the exact amount each partner earned net per month in 2005 , for eight different sources of income (including income from a paid job, and income from various benefits). When respondents would not give their exact net monthly income from these sources, for each source they were given eight categories to indicate the level of their or their partner's income. We summed all sources of income for each respondent and their partners in order to acquire a variable for net monthly household income. This method resulted in less than $1 \%$ missing values on the income variables, which were replaced with the mean income on the specific source of income.

Respondents were prompted about their traditional views on gender roles with three-five-point Likert scale items: (1) 'A working mother can be just as good a mother as a mother who stays at home for her children' (reversed); (2) 'It is not right if a man stays at home and a woman has a paid job'; (3) 'It is the task of a man to earn money and the task of a woman to care for children'. Cronbach's alpha for these three items is 0.704 .

In addition we include religious affiliation in the analyses, as we know that this is a strong determinant of traditional norms on gender roles (Jansen 2002). Households belonging to strict Protestant denominations are more likely to have traditional views of gender roles. We questioned respondents about their own religious

\footnotetext{
5 There are two missing values for educational level of the partner, which were substituted by the mean educational level, middle secondary education.

${ }^{6}$ We do not take the distribution of the tax effects of being married into account.
} 
denomination and that of their partner. With this information we computed variables indicating whether the partners form a strict Protestant couple (13\%), with nonreligious couples and couples belonging to other-less strict-denominations (Roman Catholic, Dutch Reformed Protestant) as the reference category. In the Netherlands there are several strict Protestant Christian denominations, which either are part of, or split off of the Rereformed Protestant Church. These congregations are mainly located in small towns in the upper-half of the country, in the province of Zeeland and in the Veluwe, also known as the 'Biblebelt'. Members of these congregations live according to strict religious rules, for instance, they are not allowed to use any means of transportation on Sundays and they visit church at least twice on that day. Among these people traditional gender roles are strictly enforced. We control for church attendance in times a year.

We measured the level of consensus on philanthropic donations in the household with the question whether respondents usually agree with their partner on deciding on charitable giving. Response categories include: (1) I do not interfere in donating at all (8\%); (2) we mostly disagree (2\%); (3) sometimes we agree and sometimes we disagree (11\%); (4) we mostly agree (41\%); (5) we always agree (38\%). We merged response categories 4 and 5, so that four new categories were created: respectively indicating being indifferent (response category 1), having opposing tastes (response category 2), having fluctuating tastes (response category 3), and having (more or less) similar tastes with respect to philanthropic donations (response categories 4 and 5; reference category).

As indicators for sunk costs, we include information on home ownership (69\%), number of children in the household $(\mu=1.8, \sigma=1.4)$, and whether the respondent has ever experienced a divorce $(8 \%)$.

Control variables include respondents' age (under 35 and over 65 years, with between 35 and 65 as reference category) and the dichotomous variable female $(53 \%)$ to indicate whether the respondent is female. Table 1 gives an overview of all variables used in the analyses.

\section{Results}

\section{Descriptive Results}

Figure 1 displays the amount Dutch households donated to all charitable causes (separately for total donations and for donations over $€ 50$ ), depending on how decisions on charitable giving are made in couple households.

Households in which the male partner decides on gifts are the largest donors, with an average total donation of $€ 381$. With a mean total donation of $€ 280$, households in which partners decide separately on gifts donate less. Households, in which joint decisions are made, are comparable to separately deciding couples with respect to their total donations. Their average donation is €282. Households in which the female partner decides are the smallest donors. Their average donation is $€ 127$ lower than male deciding households, $€ 254$. Who decides on charitable giving produces similar effects for both total donations and donations over $€ 50$. The only 
Table 1 Descriptive statistics for study variables (GINPS05)

\begin{tabular}{|c|c|c|c|c|c|}
\hline Variable & Obs. & Mean & S.E. & Min. & Max. \\
\hline Decision making as one economic actor & 1,101 & 0.84 & - & 0 & 1 \\
\hline \multicolumn{6}{|l|}{ Financial decision making authority ${ }^{\mathrm{a}}$} \\
\hline Male decides & 928 & 0.10 & - & 0 & 1 \\
\hline Female decides & 928 & 0.18 & - & 0 & 1 \\
\hline Couple decides jointly & 928 & 0.72 & - & 0 & 1 \\
\hline Total household donation ${ }^{\mathrm{b}}$ & 1,101 & 4.31 & 1.88 & 0 & 8.52 \\
\hline Total household donation over $€ 50^{\mathrm{c}}$ & 702 & 5.43 & 1.08 & 3.93 & 8.52 \\
\hline \multicolumn{6}{|l|}{ Marital status } \\
\hline Married & 1,101 & 0.81 & - & 0 & 1 \\
\hline Cohabiting & 1,101 & 0.14 & - & 0 & 1 \\
\hline Living apart together & 1,101 & 0.05 & - & 0 & 1 \\
\hline Divorced & 1,101 & 0.09 & - & 0 & 1 \\
\hline Church attendance $^{\mathrm{d}}$ & 1,101 & 6.70 & 21.33 & 0 & 104 \\
\hline Strict Protestant couple & 1,101 & 0.13 & - & 0 & 1 \\
\hline Traditional gender role values & 1,101 & 2.14 & 0.80 & 1 & 5 \\
\hline \multicolumn{6}{|l|}{ Tastes in giving } \\
\hline Indifferent tastes & 1,101 & 0.08 & - & 0 & 1 \\
\hline Opposing tastes & 1,101 & 0.02 & - & 0 & 1 \\
\hline Fluctuating tastes & 1,101 & 0.11 & - & 0 & 1 \\
\hline Similar tastes & 1,101 & 0.79 & - & 0 & 1 \\
\hline Mean educational level couple & 1,101 & 3.94 & 1.40 & 1 & 7 \\
\hline Educational difference $^{\mathrm{e}}$ & 1,101 & 0.24 & 1.54 & -5 & 5 \\
\hline Mean income couple ${ }^{f}$ & 1,101 & 1.10 & 0.54 & 0 & 5 \\
\hline Income difference ${ }^{g}$ & 1,101 & 0.79 & 1.02 & -4.05 & 5.50 \\
\hline Female & 1,101 & 0.52 & - & 0 & 1 \\
\hline Age under 35 & 1,101 & 0.23 & - & 0 & 1 \\
\hline Aged between 35 and 65 & 1,101 & 0.58 & - & 0 & 1 \\
\hline Age over 65 & 1,101 & 0.17 & - & 0 & 1 \\
\hline Children & 1,101 & 1.84 & 1.36 & 0 & 10 \\
\hline Home ownership & 1,101 & 0.69 & - & 0 & 1 \\
\hline
\end{tabular}

a Decision making as one economic actor, separate deciding households $(N=173)$ are excluded;

${ }^{\mathrm{b}} \ln$ (total household donation); ${ }^{\mathrm{c}} \ln$ (total household donation if over $€ 50$ ); ${ }^{\mathrm{d}}$ church attendance in times a year; ${ }^{\mathrm{e}}$ educational level husband - educational level wife; ${ }^{\mathrm{f}}$ mean income couple/1,000; ${ }^{\mathrm{g}}$ (income husband - income wife)/1,000; descriptive statistics based on first imputed dataset

small difference is that for households donating more than $€ 50$, the separately deciding households donate more than the joint deciders.

\section{Who Decides?}

Table 2 shows the results of a logistic regression analysis on whether or not couples decide on charitable donations over $€ 10$ as one economic actor. In addition, Table 2 


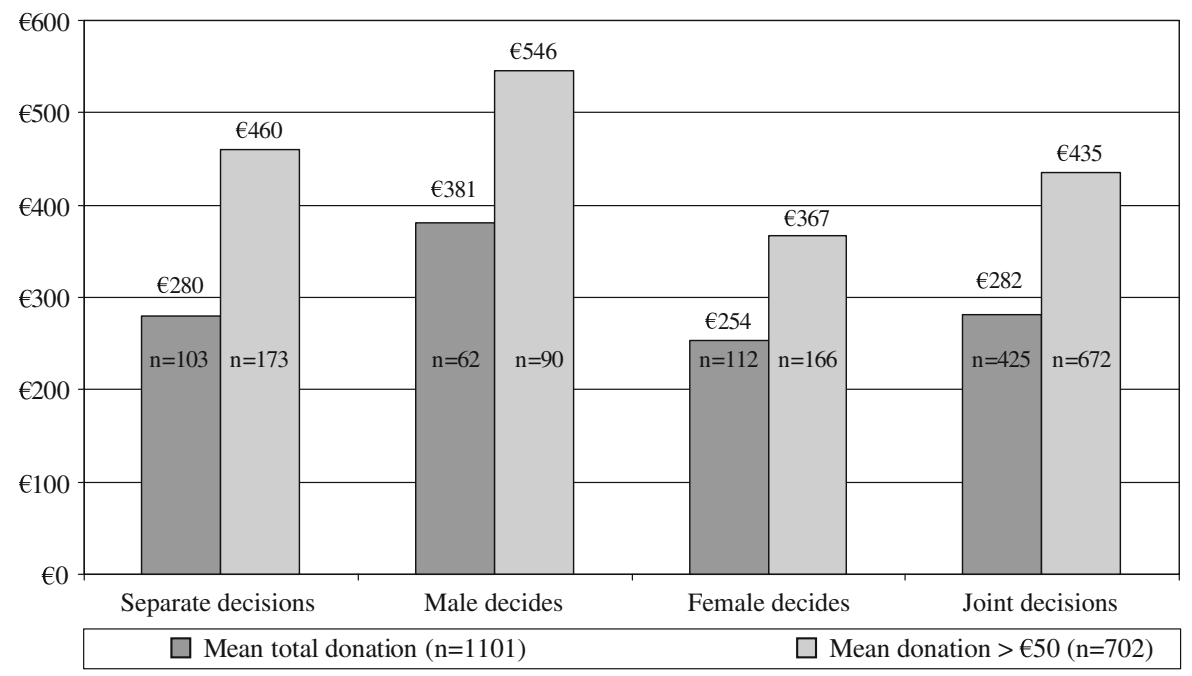

Fig. 1 Average amount donated to charitable organizations by Dutch households in 2005, depending on who in the household decides on donations over $€ 10$, for total donations and for donations over $€ 50$ in 2005 (GINPS05; results obtained with first imputed dataset)

displays the results of a multinomial logistic regression analysis on who decides on charitable donations over $€ 10$, in the case where couples make charitable decisions as one economic actor.

The absolute resource hypothesis states that couples with lower levels of resources have a higher need for pooling money, and hence make decisions on charitable giving as one actor. We find no support for this hypothesis, as there is no effect from financial or educational resources on couples making charitable decisions as one economic actor.

Furthermore, from sunk cost theory we deduced the hypothesis that the more relationship-specific investments a couple has made, the higher the probability that decisions on charitable giving are made as one actor. The results in Table 2 show partly support for this hypothesis. Home ownership has a positive effect on deciding as one economic actor, but there is no significant effect of the number of children on deciding as one economic actor. From sunk cost theory we also predicted that couples having previously experienced a serious relationship disruption prefer to act as two separate economic actors. We find support for this hypothesis, as the results show that respondents who have experienced a divorce have a larger probability of deciding on charitable giving as two economic actors.

The results of the control variables in Table 2 show that church attendance increases the probability of deciding as one economic actor, while there is no effect of belonging to a strict Protestant denomination or having more traditional gender role values. We also investigated whether different tastes for giving effect deciding as one economic actor. Although we only formulated hypotheses on the effects of tastes for giving on the amount donated to charitable organizations, it could also be the case that different tastes for giving influence the charitable decision making 
Table 2 Results of logistic and multinomial logistic regression analysis, who in a couple household decides on donations over $€ 10$ (GINPS05)

\begin{tabular}{|c|c|c|c|c|c|c|}
\hline & \multicolumn{2}{|c|}{$\begin{array}{l}\text { All couples }(n=1,101) \\
\text { Logit coefficients }(B)\end{array}$} & \multicolumn{4}{|c|}{$\begin{array}{l}\text { Couples deciding as one economic actor } \\
(n=928) \\
\text { Multinomial logit coefficients }^{\mathrm{a}}(B)\end{array}$} \\
\hline & $\begin{array}{l}\text { Deciding as one } \\
\text { economic actor }\end{array}$ & S.E. & $\begin{array}{l}\text { Female/male } \\
\text { decides }\end{array}$ & S.E. & $\begin{array}{l}\text { Joint } / \text { male } \\
\text { decides }\end{array}$ & S.E. \\
\hline Married (ref.) & - & - & - & - & - & - \\
\hline Cohabiting & 0.042 & 0.272 & -0.411 & 0.418 & $-1.070 * *$ & 0.360 \\
\hline Living apart together & 0.132 & 0.406 & 0.260 & 0.621 & $-1.603 * *$ & 0.585 \\
\hline $\begin{array}{l}\text { Mean educational } \\
\text { level couple }\end{array}$ & -0.102 & 0.071 & 0.113 & 0.118 & 0.036 & 0.104 \\
\hline $\begin{array}{l}\text { Educational } \\
\text { difference }^{\mathrm{b}}\end{array}$ & -0.047 & 0.059 & $-0.375 * *$ & 0.097 & $-0.328 * *$ & 0.083 \\
\hline Mean income couple ${ }^{c}$ & -0.091 & 0.175 & -0.204 & 0.295 & -0.182 & 0.260 \\
\hline Income difference $^{\mathrm{d}}$ & 0.038 & 0.090 & 0.040 & 0.148 & 0.098 & 0.129 \\
\hline Children & 0.101 & 0.076 & 0.146 & 0.112 & -0.123 & 0.097 \\
\hline Home ownership & $0.425^{*}$ & 0.195 & -0.012 & 0.341 & -0.377 & 0.293 \\
\hline Divorced & $-0.571^{*}$ & 0.270 & -0.591 & 0.470 & -0.328 & 0.408 \\
\hline Strict Protestant couple & -0.086 & 0.294 & $-1.536^{* *}$ & 0.473 & $-0.688^{*}$ & 0.341 \\
\hline $\begin{array}{l}\text { Traditional gender role } \\
\text { values }\end{array}$ & -0.178 & 0.116 & -0.262 & 0.188 & -0.149 & 0.160 \\
\hline Church attendance ${ }^{\mathrm{e}}$ & $0.014^{*}$ & 0.006 & 0.001 & 0.007 & 0.004 & 0.006 \\
\hline Similar tastes (ref.) & - & - & - & - & - & - \\
\hline Indifferent tastes & -0.185 & 0.300 & 0.282 & 0.384 & $-1.984 * *$ & 0.373 \\
\hline Opposing tastes & 0.059 & 0.647 & 0.444 & 0.715 & $-1.761^{*}$ & 0.726 \\
\hline Fluctuating tastes & $-0.437^{(+)}$ & 0.248 & 0.166 & 0.494 & 0.162 & 0.426 \\
\hline Female & 0.279 & 0.173 & $1.060 * *$ & 0.293 & 0.090 & 0.246 \\
\hline Aged under 35 & 0.192 & 0.250 & -0.485 & 0.407 & 0.058 & 0.351 \\
\hline Aged over 65 & -0.100 & 0.246 & -0.612 & 0.407 & -0.409 & 0.330 \\
\hline Constant & $1.995 * *$ & 0.474 & 0.682 & 0.795 & $3.636^{* *}$ & 0.676 \\
\hline
\end{tabular}

$\overline{{ }^{++)}} p \leq 0.10 ; * p \leq 0.05 ; * * p \leq 0.01$

${ }^{\mathrm{a}}$ Reference category for the equation is man is decision maker; ${ }^{\mathrm{b}}$ educational level husband - educational level wife; ${ }^{\mathrm{c}}$ mean income couple/1,000; ${ }^{\mathrm{d}}$ (income husband - income wife)/1,000; ${ }^{\mathrm{e}}$ church attendance in times a year

process. This latter effect is only limited. Only having fluctuating tastes has a negative effect on deciding as one economic actor, compared to having similar tastes (at $p \leq 0.10$ ). Couples with indifferent or opposing tastes decide as often as couples with similar tastes as one economic actor. Furthermore, female gender and age do not effect deciding as one economic actor.

The four columns on the right-hand side in Table 2 show the results of a multinomial logistic regression analysis on who decides on charitable donations over $€ 10$, in the case where couples make charitable decisions as one economic 
actor. Couples deciding as two economic actors are not considered in this analysis. The results in Table 2 compare couples in which the female partner decides with couples in which the male partner decides and jointly deciding couples with households in which the male partner decides.

From relative resource theory we deduced the hypothesis that the partner with more socio-economic resources has more power in decision making on charitable contributions. Results in Table 2 indicate that a partner's relative educational resources indeed matter for charitable decision making authority. When a male partner has a relative higher educational level, he has a higher probability of deciding on charitable giving. And vice versa for the female partner. There is no effect of partners' relative financial resources on decision making authority.

The gender role hypothesis states that the male partner is more likely to decide on charitable giving in couples with more traditional views on gender roles. The results in Table 2 show that in couples belonging to strict Protestant denominations the male partner indeed has a much higher probability to decide on charitable giving. We find no significant effect of traditional gender roles on decision making in households, although the effects are in the expected direction.

Another interesting result from the multinomial regression analysis is that married couples have a higher probability of making joint decisions than both cohabiting and LAT-couples. This result does not support the conclusion drawn from the analysis of deciding as one economic actor in Table 2. Apparently, more relationship-specific investments specifically in the form of marriage lead to deciding jointly.

The control variables show that having opposing or indifferent tastes for giving decreases the probability that couples decide jointly, compared to having similar tastes. This is interesting, apparently partners who know they do not agree with each other, or who do not care about giving avoid transaction costs for charitable giving by not deciding jointly. There is no effect of the number of children, home ownership, having experienced a divorce, church attendance, and age on who decides on charitable giving in the case of decision making as one economic actor.

A last result from Table 2 we want to point out is the large significant effect of the gender of the respondent on the gender of the partner in charge of charitable decision making. This indicates that the partner, who filled out the questionnaire, is the partner that reports to make the most decisions on charitable giving in the household. It is likely that this partner is also the most informed on charitable giving in the household, which hopefully resulted in more reliable data.

\section{Explanations for the Consequences of Financial Management}

\section{Consequences of Financial Management for Total Donations}

Table 3 shows the results of OLS regression analyses on the natural log of the total amount all couple households donated to charitable organizations in 2005. Model 3a in Table 3 includes only decision making authority. Separately deciding households donate significantly less to charitable organizations than households with male 
Table 3 Results of OLS regression analyses on the natural log of the total amount donated to charitable causes by all Dutch couple households in 2005 (GINPS05; based on nine imputed datasets)

\begin{tabular}{|c|c|c|c|c|c|c|c|c|}
\hline & \multicolumn{8}{|c|}{ All couple households $(n=1,101)$} \\
\hline & \multicolumn{2}{|l|}{ Model 3a } & \multicolumn{2}{|l|}{ Model 3b } & \multicolumn{2}{|l|}{ Model 3c } & \multicolumn{2}{|l|}{ Model 3d } \\
\hline & $B$ & S.E. & $B$ & S.E. & $B$ & S.E. & $B$ & S.E. \\
\hline Male decides (ref.) & - & - & - & - & - & - & - & - \\
\hline Female decides & -0.035 & 0.259 & 0.170 & 0.244 & -0.399 & 0.257 & 0.168 & 0.235 \\
\hline Couple decides jointly & -0.186 & 0.217 & -0.118 & 0.201 & -0.290 & 0.231 & -0.103 & 0.206 \\
\hline Separate decisions & $-0.503^{*}$ & 0.253 & -0.274 & 0.235 & $-0.596^{*}$ & 0.254 & -0.307 & 0.224 \\
\hline Church attendance $^{\mathrm{a}}$ & & & $0.022^{* *}$ & 0.003 & & & $0.020^{* *}$ & 0.003 \\
\hline Strict Protestant couple & & & $1.275^{* *}$ & 0.189 & & & $1.265^{* *}$ & 0.178 \\
\hline $\begin{array}{l}\text { Traditional gender role } \\
\text { values }\end{array}$ & & & $-0.201 * *$ & 0.069 & & & $-0.114^{(+)}$ & 0.069 \\
\hline Similar tastes (ref.) & & & & & - & - & - & - \\
\hline Indifferent tastes & & & & & $-0.896^{* *}$ & 0.258 & $-0.619^{* *}$ & 0.226 \\
\hline Opposing tastes & & & & & -0.187 & 0.517 & 0.304 & 0.452 \\
\hline Fluctuating tastes & & & & & -0.620 & 0.295 & 0.241 & 0.259 \\
\hline $\begin{array}{l}\text { Jointly decide with } \\
\text { similar tastes (ref.) }\end{array}$ & & & & & - & - & - & - \\
\hline $\begin{array}{l}\text { Jointly decide with } \\
\text { opposing tastes }\end{array}$ & & & & & -0.846 & 0.984 & $-1.521^{(+)}$ & 0.851 \\
\hline $\begin{array}{l}\text { Jointly decide with } \\
\text { fluctuating tastes }\end{array}$ & & & & & -0.274 & 0.389 & -0.549 & 0.344 \\
\hline $\begin{array}{l}\text { Jointly decide with } \\
\text { indifferent tastes }\end{array}$ & & & & & -0.374 & 0.484 & -0.367 & 0.418 \\
\hline Divorced & & & & & & & $-0.517 * *$ & 0.177 \\
\hline $\begin{array}{l}\text { Mean educational level } \\
\text { couple }\end{array}$ & & & & & & & $0.235^{* *}$ & 0.042 \\
\hline Educational difference $^{\mathrm{b}}$ & & & & & & & -0.019 & 0.036 \\
\hline Mean income couple ${ }^{c}$ & & & & & & & $0.407 * *$ & 0.115 \\
\hline Income difference $^{\mathrm{d}}$ & & & & & & & 0.052 & 0.055 \\
\hline Female & & & & & & & 0.026 & 0.106 \\
\hline Aged under 35 & & & & & & & $-0.438^{* *}$ & 0.140 \\
\hline Aged over 65 & & & & & & & $0.640^{* *}$ & 0.153 \\
\hline Children & & & & & & & $0.086^{*}$ & 0.043 \\
\hline Home ownership & & & & & & & $0.384 * *$ & 0.112 \\
\hline Constant & $4.511^{* *}$ & 0.204 & $4.519^{* *}$ & 0.249 & $4.704 * *$ & 0.215 & $2.603 * *$ & 0.336 \\
\hline$R$ square & 0.01 & & 0.17 & & 0.01 & & 0.31 & \\
\hline
\end{tabular}

$\overline{{ }^{(+)}} p \leq 0.10 ; * p \leq 0.05 ; * * p \leq 0.01$

${ }^{\mathrm{a}}$ Church attendance in times a year; ${ }^{\mathrm{b}}$ educational level husband - educational level wife; ${ }^{\mathrm{c}}$ mean income couple/1,000; ${ }^{\mathrm{d}}$ (income husband - income wife) $/ 1,000$

decision makers. Using additional Wald tests, we find no difference between female deciding and joint deciding couples (Wald test $\chi^{2}=0.80, p=0.37$ ). We do find significant differences in the amounts donated between female and separate 
deciding couples (Wald test $\chi^{2}=4.93, p=0.03$ ) and between joint and separate deciding couples (Wald test $\chi^{2}=3.64, p=0.06$ ). Separately deciding couples donate significantly lower amounts than couples with other decision making strategies. This is not what would be expected from the transaction cost hypothesis as formulated by Andreoni et al. (2003). According to this transaction costs hypothesis separate financial decision making (as two economic actors) results in higher levels of giving than financial decision making as a single actor.

The gender role hypothesis predicts that male deciding couples donate higher amounts because of their more conservative religious denomination and the more traditional gender role values connected to this religion. In model $3 \mathrm{~b}$ in Table 3 we include belonging to a strict Protestant denomination, having more traditional gender role values and church attendance as indicators for traditional gender role characteristics. These indicators suppress the significant difference in giving between separate deciding and male deciding households, and between joint deciding and separate deciding households. However, the inclusion of more traditional gender role characteristics result in a new significant difference in level of giving between female and joint deciding couples (Wald test $\chi^{2}=3.31$, $p=0.07)$. The significant difference between female and separately deciding couples remains significant in model $3 \mathrm{~b}$ (Wald test $\chi^{2}=5.12, p=0.02$ ). Once we control for traditional gender role characteristics, female deciding households are more generous than separate and joint deciding households.

Next, we consider the effect of tastes for giving in model $3 \mathrm{c}$ in Table 3. From signalling theory we derived the hypotheses that similarity in tastes for giving lead to higher charitable donations, because partners use giving in order to signal their pro-sociality. The results show that similar tastes for giving lead to higher donations. However, couples with similar tastes for giving only donate significantly more money than couples with indifferent tastes for giving. From transaction cost theory we predicted that similar tastes in giving have a positive effect on giving when couples decide jointly. Also, from transaction cost theory we derived the hypothesis that when jointly deciding couples have opposing tastes this lowers the amount donated. The interaction effects of jointly deciding and opposing, fluctuating, and indifferent tastes for giving do not differ significantly from the interaction between jointly deciding and similar tastes. At the same time, after the inclusion of tastes for giving, differences between decision making authorities remain. Specifically, the separately deciding couples donate significantly less compared to all other couples. Separately deciding households give less than male deciding households (see model $3 \mathrm{c}$ in Table 3), female deciding households (Wald test $\chi^{2}=6.85, p=0.01$ ), and jointly deciding households (Wald test $\chi^{2}=2.97$, $p=0.09$ ). Hence, the results in model $3 \mathrm{c}$ in Table 3 show no support for the transaction costs hypothesis.

After the inclusion of all predictor and control variables in model $3 \mathrm{~d}$ in Table 3 , still two differences in effects of decision making authority on charitable giving remain. Female deciding households donate higher amounts than jointly deciding households (Wald test $\chi^{2}=2.83, p=0.09$ ) and separately deciding households (Wald test $\chi^{2}=6.19, p=0.01$ ). Model $3 \mathrm{~b}$ in Table 3 shows that this effect is caused by the inclusion of traditional gender role characteristics. Another interesting 
result in the complete model is the significant interaction effect of jointly deciding and opposing tastes. Couples deciding jointly with opposing tastes for giving donate lower amounts than jointly deciding couples with similar tastes. This result provides support for the transaction cost hypothesis. This hypothesis predicted that jointly deciding couples with opposing tastes donate lower amounts.

Furthermore, in the complete model in Table 3 there is a positive effect of church attendance, belonging to a strict Protestant religious denomination, mean educational level, mean income, age, the number of children, and home ownership on total amount donated to charitable organizations. Traditional gender role values, having indifferent tastes for giving, and having experienced a divorce negatively effect total charitable giving.

\section{Consequences of Financial Management for Donations over $€ 50$}

Next, we discuss the effect of decision making authority on the level of giving, for donations over $€ 50$. The results in model $4 \mathrm{a}$ in Table 4 show that when only larger donations are considered, female deciding households donate significantly lower amounts to charitable organizations than male deciding households. Using additional Wald tests, we find no other significant differences between decision making authorities in amount donated over $€ 50$.

In model $4 \mathrm{~b}$ in Table 4, we include the indicators for traditional gender role characteristics. After this inclusion, the difference in charitable donations between male and female deciding households disappears. Both belonging to a strict Protestant religious denomination and church attendance have a positive effect on charitable donations. There is no effect of traditional gender role values on the amount households donate to charitable organizations, when considering only donations over $€ 50$. Additional analyses reveal that specifically belonging to a strict Protestant religious denomination explains the higher donations by male deciding households compared to female deciding households. ${ }^{7}$ These results provide additional support for the gender role hypothesis, specifically in the case of larger $(>€ 50)$ donations.

In model $4 \mathrm{c}$ in Table 4 we include different tastes for giving. Whether partners have similar or opposing tastes do not matter for the amount households give, considering they donate more than $€ 50$. When controlled for tastes for giving, male deciding households still donate significantly higher amounts than female deciding households. These results do not support the hypotheses derived from both signalling theory and transaction costs theory, for donations over $€ 50$.

In the complete model in Table 4 (model $4 \mathrm{~d}$ ), the results resemble the findings in models $3 \mathrm{~b}$ and $3 \mathrm{c}$. There are no differences between decision making authorities in amounts donated over $€ 50$. However, in contrast to model $3 \mathrm{~b}$, in model $4 \mathrm{~d}$ there is a slightly significant positive effect of traditional gender role values on donating over $€ 50$. This is both interesting and puzzling, as there is a negative effect of traditional

\footnotetext{
7 After separate introduction of negative gender role values and church attendance female deciding households still donate significantly less to charitable organizations than male deciding households (at $p \leq 0.10$ ). The separate introduction of strict protestant couple to the model leaves no significant difference between male and female deciding households.
} 
Table 4 Results of OLS regression analyses on the natural $\log$ of the amount donated over $€ 50$ to charitable causes by Dutch couple households in 2005 (GINPS05; based on nine imputed datasets)

\begin{tabular}{|c|c|c|c|c|c|c|c|c|}
\hline & \multicolumn{8}{|c|}{ Couple households with a total donation over $€ 50(n=702)$} \\
\hline & \multicolumn{2}{|l|}{ Model 4a } & \multicolumn{2}{|l|}{ Model 4b } & \multicolumn{2}{|l|}{ Model 4c } & \multicolumn{2}{|l|}{ Model 4d } \\
\hline & $B$ & S.E. & $B$ & S.E. & $B$ & S.E. & $B$ & S.E. \\
\hline Male decides (ref.) & - & - & - & - & - & - & - & - \\
\hline Female decides & $-0.349 *$ & 0.175 & -0.159 & 0.161 & $-0.337^{(+)}$ & 0.175 & -0.142 & 0.156 \\
\hline Couple decides jointly & -0.235 & 0.151 & -0.176 & 0.137 & -0.250 & 0.155 & -0.129 & 0.134 \\
\hline Separate decisions & -0.273 & 0.180 & -0.099 & 0.162 & -0.283 & 0.181 & -0.115 & 0.156 \\
\hline Church attendance $^{\mathrm{a}}$ & & & $0.012 * *$ & 0.002 & & & $0.011 * *$ & 0.002 \\
\hline Strict protestant couple & & & $0.523 * *$ & 0.110 & & & $0.568 * *$ & 0.106 \\
\hline $\begin{array}{l}\text { Traditional gender role } \\
\text { values }\end{array}$ & & & 0.043 & 0.051 & & & $0.097^{(+)}$ & 0.053 \\
\hline Similar tastes (ref.) & & & & & - & - & - & - \\
\hline Indifferent tastes & & & & & -0.188 & 0.205 & -0.135 & 0.180 \\
\hline Opposing tastes & & & & & -0.234 & 0.397 & -0.053 & 0.353 \\
\hline Fluctuating tastes & & & & & 0.017 & 0.225 & 0.198 & 0.194 \\
\hline $\begin{array}{l}\text { Jointly decide with } \\
\text { similar tastes (ref.) }\end{array}$ & & & & & - & - & - & - \\
\hline $\begin{array}{l}\text { Jointly decide with } \\
\text { opposing tastes }\end{array}$ & & & & & -0.179 & 0.740 & -0.659 & 0.646 \\
\hline $\begin{array}{l}\text { Jointly decide with } \\
\text { fluctuating tastes }\end{array}$ & & & & & -0.145 & 0.286 & -0.372 & 0.247 \\
\hline $\begin{array}{l}\text { Jointly decide with } \\
\text { indifferent tastes }\end{array}$ & & & & & 0.284 & 0.441 & 0.007 & 0.385 \\
\hline Divorced & & & & & & & -0.127 & 0.140 \\
\hline $\begin{array}{l}\text { Mean educational level } \\
\text { couple }\end{array}$ & & & & & & & $0.185^{* *}$ & 0.032 \\
\hline Educational difference $^{b}$ & & & & & & & -0.017 & 0.026 \\
\hline Mean income couple ${ }^{c}$ & & & & & & & 0.018 & 0.079 \\
\hline Income difference ${ }^{\mathrm{d}}$ & & & & & & & 0.032 & 0.039 \\
\hline Female & & & & & & & 0.044 & 0.076 \\
\hline Aged under 35 & & & & & & & $-0.188^{(+)}$ & 0.180 \\
\hline Aged over 65 & & & & & & & $0.367 * *$ & 0.102 \\
\hline Children & & & & & & & $0.081 * *$ & 0.030 \\
\hline Home ownership & & & & & & & $0.181^{*}$ & 0.089 \\
\hline Constant & $5.671^{* *}$ & 0.142 & $5.263 * *$ & 0.172 & $5.701 * *$ & 0.146 & $3.987 * *$ & 0.240 \\
\hline$R$ square & 0.01 & & 0.20 & & 0.01 & & 0.31 & \\
\hline
\end{tabular}

(+) $p \leq 0.10 ; * p \leq 0.05 ; * * p \leq 0.01$

${ }^{\mathrm{a}}$ Church attendance in times a year; ${ }^{\mathrm{b}}$ educational level husband - educational level wife; ${ }^{\mathrm{c}}$ mean income couple/1,000; ${ }^{\mathrm{d}}$ (income husband - income wife) $/ 1,000$

gender role values on total donations. Furthermore, there are positive effects of mean level of education, age, the number of children, and being home owner on amount donated over $€ 50$. 


\section{Conclusion and Discussion}

What are the causes and consequences of financial decision making in households in the case of charitable giving? This study shows that $84 \%$ of the Dutch couples decide on charitable giving as one economic actor. The most popular charitable decision making strategy is joint deciding. $61 \%$ of the Dutch couples decide jointly on charitable donations over $€ 10$. For all these couples, charitable giving is a household activity. This result legitimizes surveys on charitable giving investigating household giving, rather than individual giving. It also seems reasonable to question only one partner about the household's giving, as $84 \%$ of the partners in couple households will have knowledge on their household's donations.

We found support for the theory of sunk costs, as couples with more relationshipspecific investments more often decide as one economic actor. ${ }^{8}$ In addition, married couples are most likely to decide jointly, compared to cohabiting and LAT couples. For the latter two types of relationships, no specific decision making patterns emerged. This is not in line with results reported on financial management by households in the Netherlands (Giesen and Kalmijn 1999). Giessen and Kalmijn (1999) found that in 1995 in the Netherlands cohabiting couples more often have separate accounts and make individual financial decisions than married couples. An explanation for this deviant result could be the general shift from marriage towards cohabiting in the Netherlands. For younger cohorts in the Netherlands, cohabitation more and more serves as an alternative for marriage, hence cohabiting and married couples are increasingly more alike (Liefbroer and Dykstra 2000; Steenhof and Harmsen 2002). Financial decision making in cohabiting and married households could therefore also be more alike in 2005 than in 1995 .

We found no support for the absolute resource theory. There is no effect from financial or educational resources on couples making charitable decisions as one economic actor. Apparently, people do not decide as one economic actor out of the need for pooled income. We found partly support for the relative resource theory. A partner's relative educational level increases the probability that he or she decides on charitable giving. Interestingly enough, we did not find this effect for a partner's relative income level. Andreoni et al. (2003) did report a positive effect of the male partner being primary earner on having the male partner decide on charitable giving. Maybe it is not the absolute difference in income between partners that matters, but who is the primary earner. All in all, in our study only a partner's relative educational resources affect charitable decision making authority.

Furthermore, we found support for gender role theory. Couples belonging to a more conservative religious denomination have a higher probability of having the male partner decide on the household's charitable giving. However, we found no effect of having more traditional gender role values. Maybe the measure we used for traditional gender roles should have also considered values regarding handling money. The items on traditional gender roles in GINPS05 only concern values with respect to taking care of children and having paid work. It can be argued that traditional values on financial management differ to some extent from values on

\footnotetext{
${ }^{8}$ Although we did not find the expected effect of having more children on deciding jointly.
} 
taking care of children and having paid work. It is likely that this matters specifically in the case of charitable giving. Charitable donations by religious couples are, for example, often made in church. Many people can see this public act of giving, and it is likely that traditional values regarding handling money effect which partner donates, and thus very likely decides on charitable giving.

Next, we turn to the consequences of charitable decision making. A new and important result reported in this study are the different effects of decision making authority on charitable giving, depending on whether total or only larger donations are considered. When all donations are considered, separately deciding households donate the lowest amounts. This is contrary to what we expected from transaction cost theory. We expected that separately deciding partners would need to donate higher amounts to experience the same level of utility from donations as couples deciding as one economic actor. When considering total donations, we did find some support for another hypothesis derived from transaction cost theory. Jointly deciding couples with opposing tastes donate less, as donations by one partner likely create negative externalities experienced by the other partner. Fussing about giving decreases amount donated, when deciding jointly. The results on decision making patterns showed that couples avoid these negative externalities: couples with indifferent or opposing tastes have a lower probability of deciding jointly.

It is interesting that we found no support for transaction cost theory and signalling theory, when we only considered donations over $€ 50$. Only when we considered all donations, indifferent tastes lead to significant lower donations than similar tastes. We argue that this can be explained by the fact that smaller donations are usually made under some form of social pressure. Solicitors approach donors and ask them for a small gift face to face. It is very likely that these small donations are not inspired by the donor's personal preferences for a charitable organization. These petty gifts are rather motivated by the social pressure created by the solicitor, than by preferences for giving. Hence, partners that only make small donations are likely to have indifferent tastes for giving.

We found strong support for gender role theory in both the analysis of total and higher donations. Once traditional gender role characteristics are held constant for, female deciding households are more generous than separate and joint deciding households in the case of total donations. In the case of donations over $€ 50$, male deciding households no longer donated higher amounts compared to female deciding households after traditional gender role characteristics are held constant for.

What can charitable organizations learn from these results? First, when approaching couples for donations, specifically married couples will be more likely to want to decide jointly on their level of charitable giving. Fund-raisers should give married couples some time and space to be able to decide jointly. Second, our results show that the partner with the highest educational level has most decision making power. This is the partner that should be approached when asking for charitable donations. Third, it is very likely that the male partner decides on charitable giving in couples belonging to a more conservative religious denomination. In these couples fundraisers will be more successful when approaching the male partner. This is especially important, as these couples are generally large donors. 
And finally, how do these results relate to financial decision making in general? The findings on charitable decision making in this study resemble findings in general research on financial management in households. In most studies on income organization in households, joint management is the dominant strategy. For example, Treas (1993) finds that $64 \%$ of the American couples have joint bank accounts in 1984. In another study, Treas and Widmer (2000) investigate money management in 23 countries. Their results show that in Canada, the country in which couples have least often joint accounts, still $64 \%$ of the couples have joint accounts. Of course there are many differences between the specific case of charitable decision making and financial decisions in general. However, we argue that there are some general conclusions that can be drawn from this study. First, our results confirm previous research stating that partners having experienced previously marital disruption will more often decide separately on financial matters. Second, we confirm previous findings in support of relative resource theory. The partner with the highest educational level has most financial decision making power. And finally, we found support for gender role theory. Our results show that traditional views on gender roles certainly impose limits to the financial management options of women. In families belonging to more conservative religious denominations, handling money is still regarded a male task. Our study shows that this is the case for both smaller and larger financial decisions.

Acknowledgments The authors acknowledge Ineke Maas, Theo Schuyt, and Chris Einolf for their useful suggestions and remarks.

Open Access This article is distributed under the terms of the Creative Commons Attribution Noncommercial License which permits any noncommercial use, distribution, and reproduction in any medium, provided the original author(s) and source are credited.

\section{References}

Allison, D. (2002). Missing data. Thousand Oaks, CA: Sage.

Andreoni, J., Brown, E., \& Rischall, I. (2003). Charitable giving by married couples. Who decides and why does it matter? The Journal of Human Resources, 38(1), 111-133.

Bekkers, R., \& Schuyt, T. (2008). And who is your neighbor? Explaining the effect of religion on charitable giving and volunteering. Review of Religious Research, 50(1), 74-96.

Blumstein, P., \& Schwartz, P. (1983). American couples: Money work and sex. New York: William Morrow.

Botwin, M. D., Buss, D. M., \& Shackelford, T. K. (1997). Personality and mate preferences: Five factors in mate selection and marital satisfaction. Journal of Personality, 65(1), 107-136.

Brooks, A. C. (2004). What do 'don't know' responses really mean in giving surveys? Nonprofit and Voluntary Sector Quarterly, 33(3), 423-434.

Burgoyne, C. B., Young, B., \& Walker, C. M. (2005). Deciding to give to charity: A focus group study in the context of the household economy. Journal of Community \& Applied Social Psychology, 15(5), 383-405.

Buss, D. M., \& Barnes, M. (1986). Preferences in human mate selection. Journal of Personality and Social Psychology, 50(3), 559-570.

Dijkstra, P., \& Komter, A. (2004). Hoe zien Nederlandse families er uit? (How can we describe Dutch families?). Demos, 20(10), 74-77. 
Eurostat. (2005). Population and social conditions. Online database. http://epp.eurostat.ec.europa.eu (December 22 2009).

Giesen, D., \& Kalmijn, M. (1999). Het beheer van geld (The management of money). In M. Kalmijn, W. Bernasco, \& J. Weesie (Eds.), Huwelijks—en samenwoonrelaties in Nederland (pp. 105-122). Assen: Van Gorcum \& Comp.

GINPS05. (2005). Giving in the Netherlands Panel Study 2005. The Netherlands, Amsterdam: VU University Amsterdam (computer file).

Heimdal, K. R., \& Houseknecht, S. R. (2003). Cohabiting and married couples' income organization: Approaches in Sweden and the United States. Journal of Marriage and Family, 65(3), 525-538.

Jansen, M. (2002). Religiositeit en de Inrichting van het Persoonlijke Leven. Het Wederzijdse Verband Tussen Kerkbezoek, Kerklidmaatschap, Geloof en de Relatie- en Gezinsvorming Nader Beschouwd (Religiosity and the design of personal lifestyles). In M. Jansen (Ed.), Waardenorientaties en Partnerrelaties. Een Panelstudie naar Wederzijdse Invloeden (pp. 73-100). Amsterdam: Thesis Publishers.

Kenney, C. T. (2006). The power of the purse: Allocative systems and inequality in couple households. Gender \& Society, 20(3), 354-381.

Liefbroer, A. C., \& Dykstra, P. A. (2000). Levenslopen in verandering een studie naar ontwikkelingen in de levenslopen van Nederlanders geboren tussen 1900 en 1970 (Changes in life courses). Den Haag: SDU Uitgevers.

Ludwig-Mayerhofer, W. (2000). Transaction costs, power, and gender attitudes in financial arrangements of couples. In J. Weesie \& W. Raub (Eds.), The management of durable relations: Theoretical models and empirical studies of households and organizations (pp. 46-47). Amsterdam: Thela Thesis.

Lundberg, S., \& Polak, R. A. (1996). Bargaining and distribution in marriage. Journal of Economic Perspectives, 10(4), 139-158.

Milinski, M., Semmann, D., \& Krambeck, H.-J. (2002). Reputation helps solve the 'tragedy of the commons'. Nature, 415, 424-426.

Pahl, J. (1983). The allocation of money and the structuring of inequality within marriage. The Sociological Review, 31, 237-262.

Pahl, J. (1995). His money, her money: Recent research on financial organization in marriage. Journal of Economic Psychology, 16, 361-376.

Richie, J. (1990). Household allocative systems. Unpublished Working Paper.

Rooney, P., Steinberg, K., \& Schervish, P. (2001). A methodological comparison of giving surveys: Indiana as a test case. Nonprofit and Voluntary Sector Quarterly, 30(3), 551-568.

Schafer, J. L. (1997). Analysis of incomplete multivariate data. Boca Raton, FL: Chapman \& Hall/CRC.

Steenhof, L., \& Harmsen, C. (2002). Nieuwe Samenwoners (New cohabitants). Maandstatistiek van de Bevolking, 2, 7-11.

Thornton, A., Alwin, D. F., \& Camburn, D. (1983). Causes and consequences of sex-role attitudes and attitude change. American Sociological Review, 48, 211-227.

Tichenor, V. J. (1999). Status and income as gendered resources: The case of marital power. Journal of Marriage and the Family, 61(3), 638-650.

Treas, J. (1993). Money in the bank: Transaction costs and the economic organization of marriage. American Sociological Review, 58(5), 723-734.

Treas, J., \& Widmer, E. D. (2000). Whose money? A multi-level analysis of financial management in marriage for 23 countries. In J. Weesie \& W. Raub (Eds.), The management of durable relations: Theoretical models and empirical studies of households and organizations (pp. 44-46). Amsterdam: Thela Thesis.

Vogler, C. (1998). Money in the household: Some underlying issues of power. The Sociological Review, 46(4), 687-713.

Vogler, C. (2005). Cohabiting couples: Rethinking money in the household at the beginning of the twenty-first century. The Sociological Review, 53(1), 1-29.

Vogler, C., Brockmann, M., \& Wiggins, R. D. (2006). Intimate relationships and changing patterns of money management at the beginning of the twenty-first century. The British Journal of Sociology, 57(3), 455-482.

Vogler, C., Lyonette, C., \& Wiggins, R. D. (2008). Money, power and spending decisions in intimate relationships. The Sociological Review, 56(1), 117-143.

Waseem, S. (2004). Household monies and decision-making. Canberra: Social Policy Research Centre. 
Wedekind, C., \& Braithwaite, V. A. (2002). The long-term benefits of human generosity in indirect reciprocity. Current Biology, 12(12), 1012-1015.

Williamson, O. E. (1975). Markets and hierarchies. New York: Free Press.

Williamson, O. E. (1981). The economics of organization: The transaction cost approach. American Journal of Sociology, 87(3), 548-577.

Woolley, F. (2000). Control over money in marriage. Ottawa: Carlton University. 